\author{
Monika ERIKSEN \\ Jagiellonian University \\ eriksenmoni@gmail.com
}

\title{
ASSESSING RUSSIA'S DOCTRINE OF REALPOLITIK AS STRATEGIC RE-CONTOURING OF REGIONAL POWER- -BALANCE IN THE POST-SOVIET PERIPHERY
}

ABSTRACT The Ukraine conflict escalated in early 2014 and resulted in Russia's annexation of Crimea. This illustrates a troublesome pattern in the region. The author claims that this most recent political crisis is in fact emblematic of Russian's narrative for some time, as exemplified by the Russia-Georgian War, or Putin's support of Moldavian separatists. The article attempts to conceptualize Russian "mingling" in the region in light of several relevant events such as the recent creation of the Eurasian Economic Union as well as the annexation of Crimea as a deliberate strategy that reflects a much larger pattern of potential destabilization and expansionism, which begun more than a decade ago. The argument will be analyzed through the prism of two theoretical perspectives, the redefined domino theory and Kohr's power theory of social misery. Moreover, the article will place a particular emphasis on the increasing influence of the concept of Eurasianism on Russian geopolitics in recent years. The increasing regional vulnerabilities in light of Russia's antagonistic policy of Realpolitik, stresses the need for a protracted dialogue about other potential security threats that could further destabilize the region. The article discusses recent events in Ukraine as an emblematic example of Russian geopolitical strategy as a potential warning for other sovereign States in the post-Soviet "near-abroad".

Keywords: Russia, Realpolitik, Crimea, Putin foreign policy, Eurasianism 
Who rules East Europe commands the Heartland; who rules the Heartland commands the World-Island; who rules the World-Island commands the world. Harold Mackinder, 'Democratic Ideals and Reality', p. 150 (1919)

T he recent Russia-Ukraine conflict which escalated in early 2014 with the occupation of key government buildings in the country's east by pro-Russian separatists, and eventually leading to Russia's annexation of Crimea illustrates a troublesome pattern in the region. The following article presents a perhaps controversial argument which centers on Russia's politically and militarily strategic policies and maneuvers which have the potential to create a destabilizing effect in the Eastern periphery, and may be deemed as an attempt to solidify regional geo-political control. Furthermore, the author argues that the crisis in Ukraine being the most recent, is in fact emblematic of Russia's expansionist narrative for some time, as exemplified by the Georgian War, or Putin's support of Moldavian separatists. These strategically calculated maneuvers undertaken by the Kremlin seem to solidify the fear that a deliberate destabilization in the region of the former Soviet Union has in fact begun many years prior. Ukraine is emblematic of the kind of conflicts that rise from a defined set of "trigger points" that Russian government utilized to justify his regional "interventions". Namely, as in the case of Ukraine in 2014 or Georgia in 2008, an assemblage of factors such as the presence of Russian population, key geopolitical location or existing internal conflicts, have not only justified subsequent intervention, but also adversely impacted a sense of security in the most vulnerable areas in the post-Soviet periphery, such as western Kazakhstan. The article aims to further expand upon existing discourse on Russian foreign policy, analyzed through the prism of two theoretical perspectives, with a particular focus on recent political history and developments in post-Soviet periphery, under the leadership of Vladimir Putin. Moreover, the following discourse addresses the concept of Eurasianism, arguing for its influential nature in formulating Russian foreign policy, as evident from most recent developments, most notably the creation of the Eurasian Economic Union.

Russia is at a critical juncture since the collapse of the Soviet Union. In recent years especially, Russia's head of State, Vladimir Putin's approach has become deeply entrenched within the absolutist tradition, aimed at building a powerful managerial state which has allocated only relative autonomy at home. The rise of political authoritarianism has dubbed Putin's Russia a "managed democracy", with an ever-more pronounced emphasis on geopolitics. Moreover, the notion of "Putinist" foreign policy strategy in recent times to be characteristic of nationalist aspirations of rebuilding "Greater Russia", is much strengthened by the rise of a neo-Eurasian movement in recent times, led by Aleksandr Dugin, a Russian neo-fascist political thinker and geopolitician with very strong ties to Kremlin. Dugin's aggressive geopolitical visions of a united Russian empire, especially with Ukraine and Crimea, are illustrative of a Mackinderian concept of the "heartland", which will be discussed in later section, placing Russia in a privileged position as a "messianic nation" with a "unique Eurasianist mission".

A. Dugin, Foundations of Geopolitics: the Geopolitical Future of Russia, Moscow 1997. 
The general argument is that Russian foreign policy has reflected a certain momentum under the current leadership of Vladimir Putin, who, as the author argues, has consciously and from the very outset of his presidential term tried to create the necessary foundations that can secure his imperialistic aspirations. His modus operandi includes but is not limited to geo-political strategies through sometimes military means, as exemplified by Georgian War or the conflict in Ukraine, or through geo-economic strategies most notably exemplified by creation of the Eurasian Union earlier this year. Russia's antagonistic policy of Realpolitik reflects the nature of the increasing regional vulnerabilities and the strategic importance of the States over which Russian leader aims to secure control. Ukraine is notably the most important political neighbor, who prior to Russian annexation of Crimea, openly pursued closer relations with the West through NATO and its aspirations for EU membership. Naturally, the losing of Ukraine from its regional grip would signal a considerable blow to Kremlin and more importantly to Putin's long-term goals. Furthermore, Kiev's resistance of Russian interference and dominance can help to explain why Ukraine's "punishment" came down with such heavy-handedness during the 2014 conflict. Moreover, with regards to exerting Russian influence over Moldova, Vladimir Putin deliberately took advantage of the country's internal instability as it struggled to cope with the remnants of its civil war between Moldovan and Transnistrian governments. Moldova, similar to its Ukrainian counterpart, also aligned itself with Europe by signing an Association agreement in 2014.

Belarus also plays an important role here. During Yeltsin's presidency, a 1995 friendship treaty that re-emphasized the common historical and cultural bond between the two countries was signed, which eventually led to the establishment of a Union State between Russian Federation and Belarus. Upon assuming office, the Russian president strategically aimed to further advance the unification whereby Belarus would officially become a member of the Russian Federation. However, his hopes were short-lived, and the status quo remained. Furthermore, increased Western mingling in the country and the region, notably the NATO plans to deploy a missile defense system in Poland, increased US military presence in post-Soviet space, prompting Putin to exercise a series of geo-economic policies aimed at retaining regional control. One of such measures was related to Russian take-over of the Druzhba pipelines ${ }^{2}$ which led to 2007 Gas Wars.

In addition to the aforementioned examples, there is an overall sense of Russia's omnipotent and hegemonic presence lurking over the Eastern neighborhood. The conflict-ridden region marked by the Georgian civil war, secessionist wars in Abkhazia and South Ossetia, and the Nagorno-Karakbah conflict between Armenia and Azerbaijan, just to name the few, all indisputably served as an advantage in exerting Putin's control, through political or military engagement.

2 'Russia Oil Row Hits Europe Supply', BBC News, 8 January 2007, at <http://news.bbc.co.uk/2/hi/ business/6240473.stm>, 7 September 2015. 


\section{VIEWING THE PRESENT THROUGH HISTORICAL LENSES}

When the Soviet Union collapsed, the pivotal transformations that followed suit seemed to reverse the process of expanding Russian geo-political sphere of influence which began with the Russian Empire back in 17th Century. Although over the course of history its borders periodically shifted, depending on the international situation at the time, Russia has strategically aspired to expand its influence and power by becoming a key player in regional and international affairs. Once an enormous Empire, rich in natural resources, powerful and prosperous, and at its farthest point between the years 1945 and 1989 expanding as far as Central Germany. However, the political and economic disintegration of the Soviet Union in the 1990s marked a very dark period in its history. The country's borders shrank considerably and with it, so did its regional-power balance. Even during USSR's twilight years, separatist movements began to spread like wildfire across the region, and before the Federation's official demise, more than half of its republics already claimed independence. The considerable weakening of the Soviet apparatus meant that no longer would the many ethnic minorities have to be further subjected to a process of Russification. Consequently, the irreversible movements toward sovereignty of millions of ethnic minorities within the Federation served as a clear indication of the central government's waning authority. This trend affected nearly every part of Soviet Union, so much so that by 1991, fifteen new republics broke away from the Federation and created separate countries.

Russia attempted to negotiate its understanding of recent events and its national identity. The magnitude of the political and economic damage was considerable, but it wasn't long before Russia would transform its loss into a valuable learning experience, and strategically begin to reinvent itself once again as a force to be reckoned with. A coalescence of public nostalgia, when the country was at the peak of its superpower status, along with the changing political environment thrusted Russia, under new leadership, back into the game. Boris Yeltsin, who came to power by deposing the very man who gave him his political beginnings, initially seemed to inherit a country filled with optimism, hailing in a new era of democracy and economic freedom. Unfortunately, a combination of important events within the country, such as market-oriented reforms, privatization of state-controlled assets and eventual Chechnyan conflict, along with his personal shortcomings, redirected Russia on a different course away from its intended goals. By the end of Yeltsin's tenure in office, Russia's foreign policy was neither consistent, nor effective. ${ }^{3}$ Only after Yeltsin unexpectedly resigned, and Russia came under the leadership of Vladimir Putin, would status quo begin to change. Under Putin's strategic tactics, a new political blueprint would once again place Russia on the course of regional domination.

The doctrinal changes that helped to shape future Russian foreign policy were conceived prior to Putin's assuming office. In fact, almost a decade earlier nationalist or "Russian Gaullist" foreign policy was developed and promoted by Evgeny Primakov,

D. Herspring (ed.), Putin's Russia. Past Imperfect, Future Uncertain, Lanham 2003. 
a politician and diplomat who strongly defended Russia's geopolitical interests. ${ }^{4}$ It were Primakov's efforts and the subsequent drafting of a document entitled, The Foreign Policy Concept of the Russian Federation, which served as blueprint for future Russian foreign policy and more specifically, for Putin's long-term political goals. In it, a clear and precise perception of Russia's deserved and esteemed place in the world, outlining several key priorities, which include protection of Russian interests; strengthening of its sovereignty and territorial integrity; achieving firm and prestigious positions in the world community; influencing general world processes, outlining Russia's geo-political position as one of the largest Eurasian powers ... [with] its responsibility for maintaining security in the world, on both regional and global levels,... and [being] prepared to utilize all its available economic levers and resources for upholding its national interests. ${ }^{5}$

What are these national interests so often evoked in Russian rhetoric as illustrated most notably in Putin's many speeches and his current foreign policy? They of course stem from economy, regional security, political power and military superiority. Firstly however, let us briefly consider the predominant theoretical discourse that could ameliorate our understanding of modern Russian foreign policy.

\section{CONCEPTUALIZING RUSSIAN FOREIGN POLICY IN GEOPOLITICAL THEORY}

In order to better understand Russian post-Soviet foreign policy, we must keep in mind the relevance of the country's geographical parameters. Over the last century especially, many scholars, such as Emil Reich, Nicholas J. Spykaman and Alfred Thayer Mahan placed a considerable emphasis on geographical variables in international political behavior of states, with a particular emphasis on maritime strength. A state's geographic position along with its regional sphere of influence affords itself advantageous opportunities, exerting enormous impact on decision-making processes of foreign policy, thus imposing considerable limitations on opposing entities. ${ }^{6}$ At the core of this geostrategic approach in international relations has been a physio-geographically single landmass connecting two important geopolitical constituents, Europe and Asia into a portmanteau known as Eurasia. Why is this particular area of such significance, both at the time of writing by the aforementioned strategists, and more importantly in light of our discussion on Russian geopolitical ambitions? For starters, as already alluded, the area serves as a convergence between two very historically, culturally and economically important constructs covering over a quarter of Earth's total land mass. Simply put, Zbigniew Brzezinski's summary poignantly illustrates the region's enormous value:

4 B. Nygren, The Rebuilding of Greater Russia. Putin's Foreign Policy towards the CIS Countries, New York 2008, p. 19 (Routledge Contemporary Russia and Eastern Europe Series).

5 The Foreign Policy Concept of the Russian Federation, Federation of American Scientists, 28 June 2000, at <http://fas.org/nuke/guide/russia/doctrine/econcept.htm>, 7 September 2015.

6 T.V. Sevim, 'Eurasian Union: A Utopia, a Dream or a Coming Reality?', Eurasian Journal of Business and Economics, Vol. 6, No. 12 (2013), p. 44. 
Ever since the continents started interacting politically, some five hundred years ago, Eurasia has been the center of world power. A power that dominates "Eurasia" would control two of the world's three most advanced and economically productive regions. A mere glance at the map also suggests that control over "Eurasia" would almost automatically entail Africa's subordination, rendering the Western Hemisphere and Oceania geopolitically peripheral to the world's central continent. About 75 per cent of the world's people live in "Eurasia", and most of the world's physical wealth is there as well, both in its enterprises and underneath its soil. "Eurasia" accounts for about three-fourths of the world's known energy resources. ${ }^{7}$

The interest in Eurasia in the last century has been considerable generated by a number of Western powers, such as Great Britain and the United States has been considerable. Russia however, even during its Soviet Union heyday, has kept a particularly keen eye on the prize. Besides, its evident position at the cusp of Europe and Asia, with arching interests in both, Russian foreign policy in recent years has recognized the importance of "mnogopolyarnost" (multipolarity) as a key to international stability. ${ }^{8}$ Jeffrey Mankoff, an expert on Russian foreign relations equivoques the modern day multipolarity among Great Powers with nineteen century Concert of Europe. ${ }^{9}$ The European Union is an example of such arrangements, hence Russia, in the wake of post-Soviet era, has also recognized the need to create its own concert of arrangement and extend its influence, most notably in Eurasia through its carefully planned geostrategy. Geostrategists such as Alfred Thayer Mahan, long fore sought Russian's claim in the region and its potential. In his 1900 book The Problem of Asia he addresses the northern zone, located beyond the 40th parallel north (latitude) where he clearly outlines Russian Empire as the dominating force and a threat, possessing a central position in the continent. $\mathrm{He}$ also forewarns the need to limit future Russian expansionism in the area as a means to prevent predominance on the Asian continent. ${ }^{10}$ James Burnham was another geostrategist who immediately after WW II saw the Russian threat and proposed a strategy to undermine its influence in Eastern and Central Europe and beyond. ${ }^{11}$

Russia has continued to strive to keep an upper hand in the sphere of geopolitics. The theoretical foundation regarding geopolitics has been elaborated upon the works of many scholars including Friedrich Ratzel, Rudolf Kjellen, Karl Haushofer ${ }^{12}$ and Mackinder along with contemporary figures such as Zbigniew Brzezinski. The two latter strategists mentioned make an important emphasis that coincides with the discourse on modern Russian foreign policy, namely their identification of Eurasia as a geopolitically

Z. Brzezinski, The Grand Chessboard. American Primacy and its Geostrategic Imperatives (Repr.), New York 2006, p. 31.

8 J. Mankoff, Russian Foreign Policy. The Return of Great Power Politics, Lanham 2009, p. 15.

9 Ibid.

10 A.T. Mahan, The Problem of Asia. Its Effect upon International Politics, New Brunswick 2003.

11 P.F. Sempa, Geopolitics. From the Cold War to the 21st Century, New Brunswick 2009, p. 3.

12 See K. Haushofer, An English Translation and Analysis of Major General Karl Ernst Haushofer's Geopolitics of the Pacific Ocean. Studies on the Relationship between Geography and History, ed. L.A. Tambs, trans. by E.J. Brehm, Lewiston 2002 (Mellen Studies in Geography, 7). 
strategic area, which Brzezinski considers the center of the world. ${ }^{13}$ Brzezinski's contemplation is influenced by Halford J. Mackinder's Heartland Theory, which again, pays a particular focus on Eurasia as a "world-island", and within it "the heartland", comprised of Eastern and Central Europe, Western Russia, Mittleeuropa and in light of recent events particularly significant, Ukraine. ${ }^{14}$ Furthermore, his firm belief that its control by any one state would enable it to organize overwhelming human and material resources, to the detriment of the rest of the world. This is succinctly captured in his famous 1919 dictum: Who rules Eastern Europe commands the Heartland; Who rules the Heartland commands the World-Island'; Who rules the World-Island commands the World. ${ }^{15}$

Although Brzezinski's discourse is primarily focused on United States' efforts to exert impermeable influence over Eurasia as a vital center of economic growth and rising political influence, his thesis is relevant to Putin's Russia in his recognition that only when the emergence of "other" antagonistic Eurasian powers is suppressed, can a state exercise global supremacy. Geo-politicians would argue that the only state equivalent of such military and geopolitical power in the vicinity is Russia and it is she who sits astride the region referred to as "the heartland". Mackinder also stresses that any gaining control of this strategic landmass would designate the conqueror as a "pivotal state", which, as Kissinger argued in his influential book Diplomacy must be offset (he meant primarily by the United States) in order to maintain the global power balance vis-a-vis the country with a long history of expansionism (he was of course referring to Russia). ${ }^{16}$

Nicholas Spykman was yet another influential geostrategist who firmly believed that physical environment, namely geographic setting had a considerable impact on the particular trajectory of events. Similar to Mackinder, Spykman believed that the retention of world power is allotted to a state that controls what he referred to as the "Rimland". Unlike Mackinder however, Spykman believed that Eastern Europe was not the heartland that determined a state's ultimate influence on the world stage, but rather he formulated his classical realist beliefs about the concept of a pivotal state that retains control over areas comprising of Western Europe and Africa (periphery of Eurasia, what Mackinder called "marginal crescent"). Moreover, if a state controls the Rimland, then it also essentially controls Eurasia, and if the state controls Eurasia than it ultimately controls the destinies of the world. ${ }^{17}$ Immediately after WWII, the Soviet Union emerged as a force to be reckoned with, paving way for Mackinder and Spykman's theories on the significance of Eurasia to eventually bring forth various strategies of containment, as a way to limit Russian momentum. ${ }^{18}$

13 Z. Brzezinski, The Grand Chessboard ..., p. 31.

${ }_{14}$ M. Polelle, Raising Carthographic Consciousness. The Social and Foreign Policy Vision of Geopolitics in the Twentieth Century, Lanham 1999, p. 57.

15 H.J. Mackinder, Democratic Ideals and Reality. A Study in the Politics of Reconstruction, Washington 1996, pp. 175-193 (Defense Classic Edition).

16 H. Kissinger, Diplomacy, New York 1994, p. 814.

17 T.V. Sevim, 'Eurasian Union..., p. 45.

18 R. Samaddar (ed.), Space, Territory and the State. New Readings in International Politics, Hyderabad 2002, p. 10. 
The significance of geopolitics has come to have particular significance in a postCold War world, with discourse among academics and political strategists over the significance of Eurasia. Perhaps for Russia, Eurasia represents a "metaphor of a lost empire"; the nostalgic need to hang on to the notion of lost glory. ${ }^{19}$ Or perhaps, the rise of neo-Eurasianism in Russian foreign policy has less to do with emotive images of past glory but rather, according to Mozorova, is based upon an interest-based, realist rationale. ${ }^{20}$ In order to augment our discussion with clarity, let us examine Putin's Realpolitikbased expansionist policy from an economic and political perspective.

\section{RUSSIAN GEOPOLITICS: THE EURASIAN ECONOMIC UNION}

Russian pragmatism has been steadily regaining momentum for quite some time since its fall from grace in early 1990s. When Soviet Union's largest geo-political bloc disintegrated, the loss from an economic perspective was considerable, as for instance many of the productive mines of Ukraine, Kazakhstan, and Uzbekistan became no longer directly accessible. Even as far as the days of Tsarist Russia, the Caucasus region assumed enormous value, experiencing a centuries-long process of expansion during which the residing nationalities were continually subdued and gradually subjected to Russification, often at great expense. The region has retained this particular importance in the present day mainly because of its oil, its location astride Russias transportation and communications arteries leading to the Middle East. Economics undeniably play a central role in recent Russian efforts of $r e$-fusing the region under Kremlin umbrella. Aligning with neighboring states provides Russia with leverage in Europe, and abroad. Moreover, Russian long-standing efforts to push forward the idea of a regional economic union, originally introduced by Nursultan Nazarbayev, a long standing President of Kazakhstan, was a strategic necessity. Russian economic integration coming to fruition through the signing of the treaty in 2014, establishing the Eurasian Economic Union (EEU) with leaders of Belarus, Kazakhstan and Russia, possess considerable depth encompassing far beyond than just a new economic strategy. It also conveys an underlined "security" plan, by strengthening regional ties from an economic, security and political standpoint. Let us not forget that the European Union as we know it today began as European Coal and Steel Community, a regional venture with a limited initial membership, originally focused on issues related to energy, natural resources and economic integration.

The idea of EEU seems very much aligned with Russian concept of multipolarity; modeled on the European Union's economic constructs. The EU counterpart will represent a considerable market of 170 million, and will boast a total GDP of nearly

19 G. Ukhurgunashvili, Putin's Brain? Geopolitics of Aleksandr Dugin, Banska Bystrica 2015, at <https:// www.academia.edu/16094159/_PUTIN_S_BRAIN_Geopolitics_of_Aleksandr_Dugin>, 2 March 2016.

20 N. Mozorova, 'Geopolitics, Eurasianism, and Russian Foreign Policy under Putin', Geopolitics, Vol. 14, No. 4 (2009), at <http://dx.doi.org/10.1080/14650040903141349>. 
$\$ 3$ trillion. ${ }^{21}$ The EEU will extend the existing custom arrangements shared by the three nations, with of course the potential for further integration between member states.

For Russia, the EEU represents a means of mimicking the European Union in its attempt to create a parallel system of equal if not superior capability, a system of important relationships within the former Soviet Union that would not only guarantee economic alignment but eventual political consolidation similar to what we have in Europe. For many Western analysts, the creation of the EEC is a linchpin for Putin's hidden agenda, a plan for something much bigger. In a 2011 article in a Russian daily newspaper Izvestia, Vladimir Putin prophetically stated that EEC is to be a powerful supranational association capable of becoming one of the poles in the modern world. ${ }^{22}$ Although politicians of EEC member states have emphasized the fact the Eurasian Economic Union is not meant to be a political bloc, but rather a community focusing solely on mutual economic interests, there are nonetheless considerable elements already in progress that negate this supposition. In fact, the EEC in its brief existence already illustrates strikingly similar characteristics to EU's predecessor, and can every potential to extend into the political and security realms similar to present-day EU. For example, within the framework of the newly created EEU, future objectives include a single monetary union, similar to the Euro; a common customs union; single air-traffic zones, and free movement of goods, persons, capital and services. Furthermore, the EEC's composition already closely resembles the European Union: Eurasian Economic Commission, Eurasian Development Bank, Eurasian Council, Eurasian Inter-parliamentary Assembly, and the Court of the Eurasian Economic Union. ${ }^{23}$

The potential of the EEC expanding its scope of influence beyond economic integration is quite real, in fact Putin has alluded to this outline for a new world order on numerous occasions. According to The Guardian, Putin's plan is for the Eurasian Union to grow into a powerful, supra-national union of sovereign states like the European Union, uniting economies, legal systems, customs services, and military capabilities to form a bridge between Europe and Asia and rival the EU, the US, China, and India by 2015. ${ }^{24}$ Moreover, at the Valdai International Discussion Club in 2014, the Russian President stated, Russia made its choice. Our priorities are further improving our democratic and open economy institutions, accelerated internal development, taking into account all the positive modern trends in the world, and consolidating society based on tra-

21 M. Casey, 'Vladimir Putin's Impotent Eurasian Union', Foreign Policy, 5 June 2014, at <http://foreignpolicy.com/2014/06/05/vladimir-putins-impotent-eurasian-union/>, 4 March 2016.

22 V. Putin, 'A New Integration Project for Eurasia: The Future in the Making', Izvestia, 3 October 2011, at <http://www.russianmission.eu/en/news/article-prime-minister-vladimir-putin-new-integrationproject-eurasia-future-making-izvestia-3->, 10 September 2015.

23 Eurasian Economic Commission, Eurasian Economic Integration: Facts and Figures, 1 June 2015, at <http://www.eurasiancommission.org/en/Documents/broshura26_ENGL_2014.pdf>, 9 September 2015 .

24 J. Henley, 'A Brief Primer on Vladimir Putin's Eurasian Dream', The Guardian, 18 March 2014, at <http://www.theguardian.com/world/shortcuts/2014/feb/18/brief-primer-vladimir-putin-eura sian-union-trade>, 9 September 2015. 
ditional values and patriotism. ${ }^{25}$ Furthermore, he has also rejected the unipolar model, and has firmly emphasized his commitment to securing Russia as a world superpower, by stating that no one should entertain any illusions about achieving military superiority over Russia; we will never allow it. Russia will respond to all these challenges, both political and technological. We have all we need in order to do so. ${ }^{26}$ Undeniably, the necessary steps to secure Russia's economic, military and political self-sufficiency are well underway.

\section{CONCEPTUALIZING RUSSIAN FOREIGN POLICY}

Many experts have alluded to Russian foreign policy, more specifically in the last 17 years since Vladimir Putin became a central political figure, with his policies over the course of his presidency and then premiership, as being strategically geared towards satisfying his appetite for power and a stronger Russia. Putin's attempt to perhaps reSovietize the region is among some of the suppositions offered by social scientists and Russian experts. Among the multitude of expert opinions and hypotheses however, Eurasianism as a philosophical concept also attracts considerable support, in fostering a better understanding of Putin's long-term and often unpredictable political goals. The Eurasianist philosophy as a political movement has its roots in 1920's émigré communities, following the publication of Turn to the East. ${ }^{27}$ The movement attracted Russian Diaspora who began to formulate a doctrine centered on Russian civilization being a cultural amalgamation between Asia and Western Europe. Russia's geo-political and cultural legacy has always had a sense of duality, with majority of its geography located in Asia, its Slavic traditions and cultural heritage (art, music, literature) however, more closely associated with Europe. This delicate balance between two geographically and culturally opposing fronts have led to Russian identity crisis, which sparked individuals such as Nikolay Troubetskoy, Lev Gumilev and years later Vladimir Putin to adhere to a common ideological base. Eurasianists essentially believed that "Russia-Eurasia" is an entirely divergent "civilizational unit". 28 Although the theory of Eurasianism has been in existence for almost eight decades, it for the most part lay dormant as an intellectual movement, and with regards to modern-day Russia, and more specifically in light of Putin's rhetoric and foreign policy, the available writing on the subject are nonetheless rather limited and polemic in nature. One scholar who has written on the subject, Marlene Laruelle in her book Russian Eurasianism: An Ideology of an Empire believes that the aforementioned theoretical concept offers an understanding of the collapse of the

25 Meeting of the Valdai International Discussion Club, Kremlin News, 24 October 2014, at <http:// en.kremlin.ru/events/president/news/46860>, 9 September 2015.

26 Presidential Address to the Federal Assembly, Kremlin News, 12 December 2013, at <http://en.kremlin.ru/events/president/news/19825>, 9 September 2015.

27 D. Shlapentokh, Russia between East and West. Scholarly Debates on Eurasianism, Leiden 2007 (International Studies in Sociology and Social Anthropology, 102).

28 Ibid., p 6. 
Soviet Union, and consequently reestablishes Russia's troubled historical and political continuity. ${ }^{29}$

In modern Russian discourse, one figure stands at the forefront of the fascist nationalist movement, with the Eurasianist element at its core - Aleksandr Dugin, the author of his influential 600-page manifesto documenting his program for the rule of ethnic Russians over large portions of territories beyond present-day Russian borders. His militant, and perhaps to Western audiences even crude ideology is not meant to be completely dismissed regardless of its often absurd argumentation. When it comes to his influence in political life, including Kremlin, Dugin is far from being a persona non grata, in fact his ideas have infiltrated both academic and political circles, both in Soviet as well as post-Soviet periods. For example, Dugin was well acquainted with the commander from the General Staff Academy, General Igor' Rodionov who eventually became Russian Defense Minister in 1996-1997. ${ }^{30}$ This is important because it illustrates that Eurasianist ideology has been a part of Russian (then Soviet) foreign policy and political discourse for many decades, and is not a solely modern-day Russian phenomenon. Francois Thom, a French Sovietologist emphasized this very point that beginning in the 1950s, Soviet strategists like General Shtemenko and Admiral Gorshkov were inspired by Eurasianist thinking. ${ }^{31}$ Furthermore, Thom recognized the potency of Eurasianism as a movement, especially in the sphere of foreign policy as an ideological foundation for post-Soviet imperialism. ${ }^{32}$

Why is the concept of Eurasianism so embedded in Russian thought and politics? What is this intrinsic Russian connection to the Orient? The most obvious answer lies in the scope of its geographical parameters of course, but it goes much deeper than that. In fact, Eurasianism offers a scope of geopolitical arrangements, which tap into advantageous elements of both Europe and Asia. Today, there is a resurgence of neo-Eurasianist ideology in Russian political life. Why is this so significant to our discourse? The Eurasian movement has been frequently referred to as the "Greater Russia", a political aspiration of Russian nationalists and more importantly, of irredentists, to eventually merge all former Soviet republics and fuse them into a single power state. In fact, the aim of reclaiming Russian glory is illustrated in many pivotal political developments that stretch much earlier, even before Vladimir Putin took office. For example, the then Russian Vice President, Alexander Rutskoy affirmed such irredentist claims in Estonia, and Ust-Kamenogorsk Kazakhstan, ironically paving the way for President Putin to fulfill a long-term envisioned regional strategy, which in fact began in early 1990s especially with regards to Crimea, Ukraine. The idea behind "Greater Russia" has tremendous relevance in Russian political thought, and has shaped Russian foreign policy in post-Soviet environment. Putin's regional "conquests" are indubitably reminiscent of

29 D.S.Klump, Russian Eurasianism: An Ideology of Europe, Wilson Center, 7 July 2011, at <https:// www.wilsoncenter.org/publication/russian-eurasianism-ideology-empire>, 7 September 2015.

30 Shenfield, Russian Fascism. Traditions, Tendencies, Movements, Armonk 2001, p. 198.

31 F. Thom, 'Eurasianism: A New Russian Foreign Policy?', Uncaptive Minds, Vol. 7, No. 2 (1994), pp. 67-68.

$32 \quad$ Ibid., p. 76. 
Aleksandr Gelyevich Dugin's Eurasian ideological rhetoric which contends that Russia should and will re-establish itself as a global superpower, capable of challenging the geopolitical dominance and liberal ethos of the West. ${ }^{33}$ In the years immediately following the collapse of the Soviet Union, with an image of an enfeebled and reclining country, most Westerners would argue the "Greater Russia" and Eurasianist ideology as a farfetched idea. And yet twenty five years later the reality tells a different story as Putin's EEC dream comes to fruition. In fact, the foundations for Putin's expansionist goals have been laid years before. Back in 2008, Dugin, whose political ideology has had considerable influence on Putin's foreign policy, on his visit to South Ossetia prophetically stated that Russian troops will occupy the Georgian capital Tbilisi and the entire country, and perhaps even Ukraine and the Crimean Peninsula, which is historically part of Russia, anyway. ${ }^{34}$ This foreboding statement became a reality as not only did Putin support Georgian separatist militarily during the 2008 Georgian War, few years later he would also invade and successfully annex Crimea in Ukraine.

\section{THE SIGNIFICANCE OF RUSSIA'S CRIMEAN ANSCHLUSS ${ }^{35}$}

Putin-led Russian "victory" in securing a strategically important and culturally significant portion of Ukraine can be and perhaps should be treated as a warning that the West cannot afford to dismiss. As history has once before proven with Hitler and his annexation of Sudetenland in 1938, the appeasement of hegemonic ambitions comes at a very high price, and considering Europe's response (or lack thereof) to Putin's military and political tactics in Ukraine, appeasement is indeed an appropriate characterization. In the framework of our discussion on "Greater Russia”, Putin's involvement in Ukraine perhaps is more appropriately equated with Stalin's annexation of the Baltic States in 1940s. Although the Russian President has rationalized his action as merely a concerned response to the plight of his Russian-speaking compatriots (interestingly, just like Hitler once did about German nationals), his actions, however, resemble a calculated move to reassert his scope of influence further West. Moreover, the events in Ukraine carry an even bigger threat potential, as the Russian leader has stated on numerous occasions that he is willing and able to use the entire arsenal and the right of selfdefense to protect Russian speakers outside Russia. ${ }^{36}$ The recent hardliner rhetoric and,

33 R. Sibley, 'The Expansionist behind Putin', Ottawa Citizen, 1 May 2014, at <http://www.ottawacitizen.com/news/expansionist+behind+Putin/9801689/story.html>, 10 September 2015.

34 'Road to War in Georgia: The Chronicle of a Caucasian Tragedy', Spiegel, 25 August 2008, at $<$ http://www.spiegel.de/international/world/road-to-war-in-georgia-the-chronicle-of-a-caucasiantragedy-a-574812.html>, 10 September 2015.

35 The reference to Russian annexation of Crimea in comparison to German Anschluss is borrowed from: V. Davidoff, 'Putin's Crimean Anschluss', The Moscow Times, 3 March 2014, at <http://www. themoscowtimes.com/opinion/article/putins-crimean-anschluss/495462.html>.

36 T. Parffit, 'Has Vladimir Putin Blinked over Ukraine?', The Daily Telegraph, 7 July 2014, at <http:// www.telegraph.co.uk/news/worldnews/vladimir-putin/10951644/Has-Vladimir-Putin-blinked-over-Ukraine.html>, 10 September 2015. 
more importantly, Russian action in Ukraine, set an alarming precedent for Russian's regional neighbors.

The recent events in the region, namely the Ukrainian conflict, have been alarming, but the varying level of discordance comes from understanding the very nature of Russian motivations and foreign policy. The first proposition come from those scholars who fervently defend a realist approach in international relations that places State's interest as a priority, underlining that predatory behavior is motivated by the quest for increased military, economic and political power on the world stage. John Mearsheimer, an American political scientists and a founder of offensive realism, is a firm adherent to the realist school. He believes that great powers, such as Russia for example, are motivated by rational desire in order to secure world hegemony. In his influential book, The Tragedy of Great Power Politics, he asserts that aggression comes from the structure of international system [which] forces states to seek only to be secure, nonetheless to act aggressively ... Cause [ing] states to fear one another. ${ }^{37}$ If Mearsheimer's argument is applied in the context of Russian aggression in Ukraine, then the decision to annex Crimea is a direct result of larger strategies by the West to remove Ukraine from Russian orbit. ${ }^{38}$ Examples of Western aggression such as the EU and US's support of pro-democracy movements such as the Orange Revolution back in 2004, the overthrowing of a proRussian president of Ukraine Viktor Yanukovych, or the NATO enlargement in the eastern neighborhood can be deemed explanatory for Putin's counteroffensive with regards to Ukraine. Certainty, Putin's aims to minimize Western and American influence in his backyard as an argument for his Realpolitik foreign policy has its share of proponents.

From a purely economic standpoint, annexing Crimea did little to boost the Russian economy, as majority of Crimean economy is based upon tourism and agriculture. There is of course the issue of oil. The peninsula does indisputably possess natural gas, and following the annexation, Russia can eventually claim the added nautical miles from the Crimean coast under the 1982 UN Law of the Sea Treaty, ${ }^{39}$ with exclusive right to exploit the area's potential large reserves of oil and natural gas. Or perhaps, Russian control of offshore natural gas resources may place Ukraine in a more vulnerable position, forcing it to increase its reliance on Russia, thus ensuring its minimized relationship with the West. On the other hand, the counter argument could outline that Russia's annexation of Crimea might spell far more disadvantages than economic benefits, such as a recession, decrease or withdrawal of foreign investors a pronounced conflict with the West.

The other argument that can be made for explaining Russian foreign policy is ideologically-based. It deals with Russian nationalist sentiments and historical legacy.

J.J. Mearsheimer, The Tragedy of Great Power Politics, New York 2001 (The Norton Series in World Politics).

38 Idem, 'Why the Ukraine Crisis is the West's Fault', Foreign Affairs, Vol. 93, No. 5 (2014), at <https:// www.foreignaffairs.com/articles/russia-fsu/2014-08-18/why-ukraine-crisis-west-s-fault>, 3 March 2016.

39 See The United Nations Convention on the Law of the Sea, at <http://www.un.org/depts/los/conven tion_agreements/texts/unclos/unclos_e.pdf $>$. 
After all, Crimea was once a part of the Russian empire. Emotional resonance of a nation in regards to a territory that has established historical, cultural and linguistic ties can be a very powerful motive for variety of action. Kosovo for the Serbian nation is one example that quickly comes to mind as means of illustrating this point. Historical and geographic identity can play a profound role in shaping policies and the future of international relations. This particular motive can arguably be even more potent than any justification realists can propose, because it can transcend to the very core of a nation allowing the governing elites, in this case Putin, to rally up the support for this foreign policy. One feature of the identarian discourse with regards to Ukraine was based upon the large Russian-speaking population. If this was in fact the primary motive, then the potential for future aggression against countries in the region with similar demographics is considerably higher. Let us consider this aspect a bit further.

In Central Asia, Kazakhstan is home to 18 million people, 23\% of which are ethnic Russians, and Russian language being the second official language with about $95 \%$ of population using speaking Russian as means of interethnic communication, while Kyrgyzstan is also home to substantial ethnic Russian minorities, which retained Russian as a state language. ${ }^{40}$ In Uzbekistan, a state which sought rapprochement with Moscow in the wake of the 2005 Andijan revolt, education policy has sought to reemphasize Russian in schools. ${ }^{41}$ With regards to Belarus, a historically key Russian ally, ethnic Russians account for approximately $8.3 \%$ of the population while Russian remains an official language spoken by $70 \%$ of the population. In Estonia, approximately $25 \%$ of the population is ethnic Russians and nearly 30\% speak Russian, while Latvia is comprised of approximately $26 \%$ ethnic Russians and 33\% Russian speakers. ${ }^{42}$

For mother Russia, safeguarding the linguistic rights of the nearly 25 million ethnic Russians and Russian speakers has been a salient foreign policy objective, one that has raised concerns over state sovereignty. Furthermore, past and recent Russian expansionist claims are more than just a supposition of the West, in fact it is a stated objective in the Foreign Policy Concept of the Russian Federation to promote and propagate, in foreign states, Russian language, as well as to protect rights and legitimate interests of the Russian citizens and compatriots living abroad... including for expanding and strengthening the space of the Russian language and culture. Considering that rhetoric could be applicable elsewhere, as it has already been once in recent times, as exemplified by the Ukrainian conflict, it can be safely inferred that Russian Realpolitik only foretells a concerning forecast for the future - a forecast that spells for a destabilization of the eastern periphery and a gradual seizure of power. For many of the Russia's neighbors, the stated "concern" over the protection of linguistic rights is viewed as a smokescreen for Russian hidden agenda, one that aims to increase Russian influence, incurs a deliberate interfer-

40 Central Intelligence Agency, World Factbook: Kazakhstan, 2015, at <https://www.cia.gov/library/ publications/the-world-factbook/geos/kz.html>.

41 Y. Khalikov, Uzbekistanis Russian-Language Conundrum, Eurasianet, 18 September 2006, at <http:// www.eurasianet.org/departments/insight/articles/eav091906.shtml>, 10 September 2015.

42 Central Intelligence Agency, World Factbook: Estonia, Belarus, Latvia, Ukraine, 10 IX 2015. 
ence in the sovereignty of the ex-Soviet satellites, and ensures economic and political destabilization of the region which will ultimately secure Russian domination.

In light of the ethnic composition of most states in the "near-abroad", statements made by Putin to the U.N Secretary General Ban Ki-moon noting that in case of any escalation of violence against the Russian-speaking population of the eastern regions of Ukraine and Crimea, Russia would not be able to stay away and would resort to whatever measures are necessary are certainly a cause of concern. ${ }^{43}$ As already mentioned, nearly every state in former Soviet Union contains a considerable Russian-speaking and ethnic population. The brevity and at the same time alarming nature of the aforementioned statement, among many others made, assumes a right to invade any sovereign country so long a perceived threat against such population is apparent. There seems to be no room for any legitimacy or justification of such an assumed "threat", which inarguably leaves Russian neighbors in a state of continued vigilance and fear. Naturally, such states have, as in the case of Georgia and Ukraine, sought closer alliance with the West, through for example a membership in NATO and the European Union. In an effort to counter such unfavorable developments, Russia would naturally reaffirm its geo-political ties with Asia, namely China as illustrated by these long-standing Eurasian policies.

In the context of Russian foreign policy with regards to Crimea, it is important to consider the likelihood of regional destabilization and its effects on weaker states such as Kazakhstan for example. Surely, while Nazarbayev remains in power we can assume the sovereignty of Kazakhstan may remain intact, for after all, the idea behind Russian most recent regional collaboration, namely the EEU is Nazarbayev's brainchild. For now, both leaders have maintained their relationship mutually amicable, but the Kazakhstan's President is undeniably an aging man (76), whose quarter century-long rule in the country has yet to outline a clear succession path. The concern over a "Ukrainian scenario" is a viable possibility following Nazarbayev's departure. And perhaps Putin's chilling statements about the nature of the titular ethnicity of one the key Central Asian countries in Russian near-abroad - where he said that Kazakbs had never had statehood $^{44}$ - may provide a clue to what may be ahead for Kazakhstan. Nazarbayev has been a central role in safeguarding Kazakhstani nationalism. It is also important to point out that Kazakhstan does contain ethnic Russians within its borders, and history tells us that any forms of counter-nationalism wasn't well received by Russia. Hence, we can perhaps infer that since Putin believes that Kazakhs are part of a territory without being a legitimate state whose nationalistic fervor may threaten Russian interests, the "Ukrainian scenario" seems far more plausible than we may think.

We might wonder how such a grandiose plan could be put in the works undetected. The irony of the situation is that Putin's blueprint is not being hidden from public view, in fact his Eurasianist ideology and belief about Russia's place in the sun is being

43 Telephone Conversation with UN Secretary General Ban Ki-moon, President of Russia, Kremlin, 2 March 2014, at <http://en.kremlin.ru/events/president/news/20357>, 14 September 2015.

44 M. Eckel, 'Ukraine War, Putin's Comments Stirr Worry in Kazakhstan', Voice of America, 7 September 2014, at <http://www.voanews.com/content/russia-kazakhstan-ukraine-fears/2440051.html>, 4 March 2016. 
openly proclaimed. For instance, in an article published in the Nezavisimaya Gazeta daily, Putin states that Russian people are nation-forming ... the great mission of Russians is to unite, and bind the civilization..$^{45}$ Certainly the scope of Putin's strategy remains unknown but it is perhaps appropriate to consider that diversion as a tactic is part of it. Is this at all feasible? The answer lies in world events. During the Cold War, the United States kept a tab on only one, visible, known enemy thus making the task considerably easier. In today's global environment, the threat of communism has been replaced by terrorism and Islamic extremism. The United States with its allies are in the business of fighting a multifront war with an invisible enemy. The rules of the game are far different thus requiring more attention and resources. Such geo-political circumstances can be to Russian advantage. The ability to distract the US is more feasible, as the Americans are already quite busy with the War of Terrorism and the complex events in the Middle East. Furthermore, closer to home, the European Union like its American counterpart has also a lot on its plate in recent times. With the financial crisis sweeping the continent, anti-austerity protests and concern over "Grexit", Euroscepticism, and now the enormity of the migration crisis, the European Union's attention is certainly divided. Russia had certainly come very far from its weak circumstances under Yeltsin; reborn under a centralized government and a power military force at the heart of the country. And as George Friedman, an American political scientist and intelligence analyst, accurately pointed out - Moscow once again dominates Russia. At the present moment, Putin dominates Moscow. Russian foreign policy and recent undertakings in the "near abroad" are aimed to dominate the former Soviet Union. Russian most significant adversary, the US, is distracted in the Middle East, while its neighbor to the West, the European Union is destabilized and split. ${ }^{46}$ Consequently, what we can infer from the current geo-political picture is that the potential of Russian long-term goals have far more chances of becoming a reality than we realize, especially when a policy of appeasement is added to the mix.

\section{DOMINO THEORY RE-DEFINED}

As a result of this most recent Russian movement to seize and then annex the Crimean Peninsula, analysts, politicians, and experts are now trying to fully come to grips with Russian motivations. The pressing issue isn't only to understand what has already happened, but perhaps the more important aspect is try to evaluate what comes next, of course. Being a step ahead in international relations is always a good idea, especially when the stakes are high. One theoretical model can be applied to our discourse on Russia's expansionist conquests is the domino theory. At the time of its inception, the American President Dwight D. Eisenhower described the series of unfolding political

45 V. Putin, Integration of Post-Soviet Space an Alternative to Uncontrolled Migration, RT News, 23 January 2012, at <http://www.rt.com/politics/official-word/migration-national-question-putin-439/>, 11 September 2015.

46 G. Friedman, 'Russia Rising Again?', Catholic Exchange, 3 May 2012, at <http://catholicexchange. com/russia-rising-again >, 12 SEptember 2015. 
events that, ironically enough, were also related to Russian (then Soviet) foreign policy and consequent regional aggression. In the years to follow, Henry Kissinger further expanded on this theoretical model. Following World War II, the West became concerned about the spread of Communist ideology through Soviet propaganda. The central principle of the domino theory states that if one Communist country fell, others would soon follow. The analogy of "falling dominos" was consequently applied in the context of American involvement in Vietnam as well as a subsequent justification to combat communism around the world.

Although the Cold War is long over, the key protagonist from the past remains on the forefront today, except that no longer are we talking about the proliferation of Communist ideology but rather, Eurasian ideology supplemented with Putin's calculated efforts to regain complete control in the post-Soviet periphery. The same logic can be applied here if the domino theory is restructured by substituting prevailing characteristics, originally meaning Communism to now, Russian destabilization and military hegemony of the region. Instead of "falling" Vietnam, Cambodia, Laos, Thailand or Burma, the relevant players could potentially be for instance Georgia, Uzbekistan, Belarus, Kyrgyzstan, or Estonia. Russia's efforts can be analyzed in the framework of neo-Domino Theory, or Domino Theory re-defined. The Domino Theory helps to symmetrically analyze crucial historical events and recent trends that correspond to Russian foreign policy objectives and national security strategies.

Government leaders, civil society from all surrounding States, including Georgia, Armenia, Moldova, and Kazakhstan are all anxiously watching the events that have been unfolding in their very backyard with justified fear that the same Russian aggression that engulfed their Ukrainian neighbor might very well infiltrate their borders, and in some case, infiltrate them again. If the EU and the United States within the NATO framework fail to adequately support Ukraine, then based upon the above hypothetical presumptions, Russia can very well continue to "intervene" and thusly destabilize, like a falling domino, other regional States one by one, such as Estonia or Latvia which have considerable Russian speaking minorities.

\section{BIGGER, STRONGER, AND MORE AGGRESSIVE: RUSSIA IN FRAMEWORK OF KOHR'S POWER THEORY OF SOCIAL MISERY}

Another theoretical model worth mentioning in our effort to conceptualize Russia's geo-political endeavors in the last two decades is Leopold Kohr's power theory of aggression, or power theory of social misery. Kohr's theory outlines that there is a causal relationship between excessive acquired size which leads to excessive power, and the tendency towards aggression, belligerence and war. ${ }^{47} \mathrm{Kohr}$ argues that once a nation becomes large enough to accumulate enough power, it will undoubtedly become an aggressor. Historically, this principal was most notably exemplified by Hitler's Germany 
at the height of its power, and Napoleon's France. Moreover, this logic was applicable to Russia during the days of the Soviet Union. The core of its eventual strength, both political and military, was founded in its geographic acquisition. As the Soviet Empire grew, so did its hegemonic tyranny which translated into enormous social misery of the people it dominated. Today, Putin-led policies seem to be placing Russia on a similar path as its predecessor. Some critics would argue that his political rhetoric coupled by decisive action can be seen as "pushing the envelope" with Russian "intervention" in Chechnya, Moldova, Georgia but Ukraine represents a tangible and unmistakable move forward in changing the geo-political landscape of the eastern periphery. Interestingly, Kohr believed that when a nation reaches its "critical volume", despite the ambitions of its leaders, no ideology, can prevent it from exploding into hostility. By the same token, no ideology such as Eurasianism or expansionism can push a nation into aggression or warfare so long as it remains small. Hence, what we can deduct from this reasoning is that appeasing Putin's Eurasian ideology, coupled with his expansionist Realpolitik foreign policy can foretell further aggressive "intervention", ultimately leading to regional destabilization and the expansion of Russia's "critical volume". Moreover, Kohr protested against the "cult of bigness" from an economic perspective, calling for the dissolution of large centralized structures. Russia's most recent venture, the Eurasian Economic Union, can certainly be conceptualized in Kohr's theoretical framework, which according to his argument would treat this regional project as a source of aggression, war and social misery. For Kohr, it isn't about the union of things, but about its division.

Lastly, Kohr further suggests that a legitimate democracy can only be achieved when citizens exert a healthy level of direct influence over the government, which can only truly be established in small states. Certainly, Putin's Russia cannot be called a true democracy for reasons generally known, but which should be discussed further elsewhere.

\section{RUSSIA'S UNCHECKED AGGRESSION: A COMMENTARY ON THE DERISORY NATURE OF THE INTERNATIONAL RESPONSE}

The stance of the West and Russia in recent years can be characterized as two-fold: appeasement and tenacious impudence. It isn't difficult to decipher which of these two is attributed to Mr. Putin and which one to the West. For all of Russian military and political "chest-beating" in recent years, coupled with acts of aggression in the "near abroad", Russian boldness is a force to be reckoned with. And why should Russian confidence be curtailed, since the magnitude of American and European response has been adynamic? Let us briefly outline some of Russia's regional undertakings in recent years, and compare it with the West's subsequent response.

For Russian military involvement in the Second Chechnyan War in 1999, the international community's rhetoric was one of condemnation and cautioning. The United Kingdom Secretary of State for Foreign and Commonwealth Affairs Robin Cook has 
wholeheartedly ... condemn[ed] vigorously what Russia is doing in Chechnya. ${ }^{48}$ Furthermore, the denunciation was accompanied by economic ultimatums which included economic sanctions and international isolation. Following the conflict, the United Nations Commission for Human Rights called on Russia to establish an independent commission to document and investigate human rights abuses, violations in an effort to bring perpetrators to justice. However, Russian has yet to fulfill all of the above requirements.

Less than a decade later, the country becomes involved in the Russo-Georgian War of 2008, offering military and political support to Ossetian separatists. The strained Russo-Georgian relations were already considerably tense years prior, when Georgia decided to join the Commonwealth of Independent States, a move Putin strongly opposed. Furthermore, the Georgian efforts to peacefully reintegrate South Ossetia into the country were continually sabotaged, most notably by Putin-led "passportization" policy - a mass-scale distribution of Russian passport to residents of Abkhazia and South Ossetia. Such action was of course seen as means of Russia laying the necessary foundations for his future claim over these territories ${ }^{49}$. The response was similar to Russian intervention in Chechnya, a policy of overt condemnation. The then US President Bush stated that Russia has invaded a sovereign neighboring state and threatens a democratic government elected by its people. Such an action is unacceptable in the 21st century. ${ }^{50}$ Moreover, similarly to the previous regional conflict, the hard talk was augmented by threats of economic sanctions, which although implemented were subsequently revoked by Barack Obama two years later. ${ }^{51}$ The Georgian embassy in London has openly accused Russia of attempting to "conquer" Georgia. And despite the US along with its Western allies waving a big stick, in the end the hardline rhetoric was all that followed suit. Although the Bush administration entertained the possibility of a direct military intervention to defend Georgia, ultimately the plan was abandoned in an effort to prevent an open conflict with Russia. The few aforementioned examples clearly illustrate an appeasing stance of the West towards Russia's imperialistic tendencies.

Furthermore, nearly six years later, Russia once again "intervenes" in the "near abroad", this time however with much greater tenacity and force, and unlike previous "mingling" in Chechnya and Georgia where the extent of his undertakings was limited to military support to Russian separatists, his directives in Ukraine illustrated a far more ambitious plan. Taking advantage of the turbulent developments in the wake

48 'UK Condemns Chechnya Ultimatum', BBC News, 7 December 1999, at <http://news.bbc.co.uk/2/ hi/uk_news/politics/554075.stm>, 13 September 2015.

49 M. van Herpen, Putin's Wars. The Rise of Russia's New Imperialism, Lanham 2014.

50 L. Harding, I. Traynor, 'Russians March into Georgia as Full-scale War Looms', The Guardian, 12 August 2008, at <http://www.theguardian.com/world/2008/aug/11/georgia.russia13>, 13 September 2015.

51 P. Baker, D.E. Sanger, 'U.S. Makes Concessions to Russia for Iran Sanctions', The New York Times, 21 May 2010, at <http://www.nytimes.com/2010/05/22/world/22sanctions.html?_r=0>, 13 September 2015. 
of the Ukrainian Revolution and ousting of then-President of Ukraine Viktor Yanukovych, Russia disregarded Ukrainian sovereignty by forcefully occupying and subsequently annexing a portion of its territory, namely the Crimean Peninsula. Considering the scope of Russian aggression and undisputable violation of international law, a harsh, unified and unyielding stance is expected from the international community. And yet, just as Russian foreign policy yielded the same results years' prior - military intervention and control - so the warnings of the West failed to escalate beyond empty rhetoric. In response to Russia's illegal annexation and subsequent destabilization of the region, the scope of the international response centered on diplomatic measures such as the canceling of EU-Russia summit, or economic measures such as freezing of assets, limited financial transaction with Russian banks and embargos on arms from/to Russia. ${ }^{52}$ Once again, Europe and the United States pledging their fierce and sweep justice against the Russian aggression turned out to be toothless. The most recent aggression in the last 15 years clearly illustrates an interesting paradox: neither are Russia's policies being accordingly adjusted to international "pressures", nor are the international "pressures" capable of adjusting accordingly Russia's expansionist policies. For the most part, the West has declined to implement any long-term deterrent measures against continued Russian expansionism. As a consequence to Russian invasion of Georgia in 2008, the aggressor went virtually unpunished. In fact, virtually four years to the date following its aggression in Georgia, it was finally awarded membership in the World Trade Organization after nearly 18 years of negotiations. ${ }^{53}$

Up until now, documented international acquiescence of Russia's behavior essentially allows this superpower to intimidate and subsequently topple sovereign democracies without serious repercussions. A policy of appeasement is a colossal miscalculation with potentially catastrophic consequences. Will the international community's response illustrate a stronger stance than that exhibited in the case of the Ukrainian crisis? The need to re-analyze the potential for old frozen conflicts to reignite as a result of Russia's renewed political aspirations seems timely in the least; recent Ukrainian conflict also probes further the need to re-asses regional alliances and relationships within the framework of the EU's Eastern Partnership.

\section{CONCLUDING REMARKS: RUSSIA'S POLICY OF REALPOLITIK AND ITS LONG-TERM RAMIFICATIONS}

Most of Russia's targeted post-Soviet states are young democracies who are not immune from political problems and challenges. Safeguarding their sovereignty is in everyone interest. Geo-political heritage of the states in Russia's "near abroad" seems to

52 EU Sanctions against Russia over Ukrainian Crisis, European Union Newsroom, at <http://europa. eu/newsroom/highlights/special-coverage/eu_sanctions/index_en.htm>, 13 September 2015.

53 World Trade Organization, WTO membership rises to 157 with the entry of Russia and Vanuatu, $22 \mathrm{Au}-$ gust 2012, at <https://www.wto.org/english/news_e/pres12_e/pr671_e.htm>, 13 September 2015. 
be a curse; having secured their respective sovereignty just to be put on high alert once again by the very same protagonist. Where international acquiescence over Georgia was seen as a "slap" to Russia, the pronounced brevity of its decision to annex Crimea now demands a unified international "punch".

The debate over the West's response to Russian foreign policy in the eastern periphery is characteristic of an ongoing policy of appeasement. It is, however, important to keep in mind the importance of a strong, unified stance of the international community against Russian expansionist policies in the "near abroad", as a measure to prevent further regional destabilization, and the eruption of new conflicts. The Russian policy of Realpolitik is a serious threat to the stability of the region. The West must absolutely at all costs make clear that Russia's current foreign policy is antithetical to its own stated goals of being a respected member of the international community.

If Putin-led Eurasian ideology and foreign policies continue to manifest themselves in acts of aggression and expansionism against its neighboring states, the consequences in the region and beyond may be severe. It is foolish to dismiss Russia's foreign policy policies and take Putin's rhetoric for granted. After all, Russia is a state with nuclear capabilities. According to the Federation of American Scientists, Russia in 2013 possessed an estimated 8,500 nuclear warheads of which 1,800 were strategically operational. ${ }^{54}$ As Zbigniew Brzezinski rightfully noted, much depends on how the West conveys to the dictator in the Kremlin that NATO cannot (and should not) stand by if war erupts in Europe. And if Ukraine is crushed while the West is simply watching, the new freedom and security in bordering Romania, Poland would also be threatened. ${ }^{55}$ Unfortunately, as is the case in Chechnya, Georgia and now Ukraine, it is the average citizens who are always the ones to pay a heavy price for the lack of historical knowledge and lack of unified and tenacious action of their politicians. Today it is Ukraine, but tomorrow it might be citizens of Estonia, or Latvia, or any other former Soviet republic.

To conclude, a statement made by an American Senator from Connecticut, Christopher J. Dodd, in front of the US Senate Committee on Foreign Relations, immediately following Russia's aggression against Georgia, prompts us to seriously ponder on the potential ramifications of Russian policy of Realpolitik in the near future:

Geopolitically we are witnessing a turning moment in history. The only question is what turning point? Will it mark the moment Russia recognized the political and economic costs of military conflict with its neighbors was probibitively high and permanently abandon the practice, or will it usher in a new era of insecurity in which no country in the region, Russia included, feels confident in its ability to prosper in the absence of outside pressures. How the United States and its allies respond not only in the coming days, weeks and months

54 H.M. Kristensen, R.S. Norris, Status of World Nuclear Forces, Federation of American Scientists, 16 July 2009, at <http://fas.org/issues/nuclear-weapons/status-world-nuclear-forces/>, 13 September 2015 .

55 Z. Brzezinski, 'Zbigniew Brzezinski: After Putin's Aggression in Ukraine, the West Must Be Ready to Respond', The Washington Post, 3 March 2014 at <https://www.washingtonpost.com/ opinions/zbigniew-brzezinski-after-putins-aggression-in-ukraine-the-west-must-be-ready-torespond/2014/03/03/25b3f928-a2f5-11e3-84d4-e59b1709222c_story.html>, 13 September 2015. 
but over the coming years ... will have a significant impact on determining which of these scenarios comes to be the case. ${ }^{56}$

\section{BIBLIOGRAPHY}

Baker P., Sanger D.E., 'U.S. Makes Concessions to Russia for Iran Sanctions', The New York Times, 21 May 2010, at <http://www.nytimes.com/2010/05/22/world/22sanctions. $\mathrm{html}$ ? $\mathrm{r}=0>$.

Brzezinski Z., The Grand Chessboard. American Primacy and its Geostrategic Imperatives (Repr.), New York 2006.

Brzezinski Z., 'Zbigniew Brzezinski: After Putin's Aggression in Ukraine, the West Must Be Ready to Respond', The Washington Post, 3 March 2014 at <https://www.washingtonpost. com/opinions/zbigniew-brzezinski-after-putins-aggression-in-ukraine-the-west-must-beready-to-respond/2014/03/03/25b3f928-a2f5-11e3-84d4-e59b1709222c_story.html>.

Casey M., 'Vladimir Putin's Impotent Eurasian Union', Foreign Policy, 5 June 2014, at <http:// foreignpolicy.com/2014/06/05/vladimir-putins-impotent-eurasian-union/ $>$.

Central Intelligence Agency, Belarus World Factbook, 2015, at <https://www.cia.gov/library/ publications/the-world-factbook/geos/bo.html>.

Central Intelligence Agency, World Factbook: Kazakhstan, 2015, at <https://www.cia.gov/ library/publications/the-world-factbook/geos/kz.html>.

Davidoff V., 'Putin's Crimean Anschluss', The Moscow Times, 3 March 2014, at <http://www. themoscowtimes.com/opinion/article/putins-crimean-anschluss/495462.html>.

Dodd Ch.J., Russia's Aggression against Georgia: Consequences and Responses, US Senate Committee on Foreign Relations, 17 September 2008, at <http://babel.hathitrust.org/cgi/pt?id $=$ pst.000065526903; view=1up;seq=5>.

Eckel M., 'Ukraine War, Putin's Comments Stirr Worry in Kazakhstan', Voice of America, 7 September 2014, at <http://www.voanews.com/content/russia-kazakhstan-ukrainefears/2440051.html>.

EU Sanctions against Russia over Ukrainian Crisis, European Union Newsroom, at $<$ http://europa.eu/newsroom/highlights/special-coverage/eu_sanctions/index_en.htm $>$.

Eurasian Economic Commission, Eurasian Economic Integration: Facts and Figures, 1 June 2015, at $<$ http://www.eurasiancommission.org/en/Documents/broshura26_ENGL_2014.pdf $>$.

The Foreign Policy Concept of the Russian Federation, Federation of American Scientists, 28 June 2000, at <http://fas.org/nuke/guide/russia/doctrine/econcept.htm>.

Friedman G., 'Russia Rising Again?', Catholic Exchange, 3 May 2012, at <http://catholicexchange.com/russia-rising-again $>$.

Harding L., Traynor I., 'Russians March into Georgia as Full-scale War Looms', The Guardian, 12 August 2008, at <http://www.theguardian.com/world/2008/aug/11/georgia. russia13>.

56 Ch.J. Dodd, Russia's Aggression against Georgia: Consequences and Responses, US Senate Committee on Foreign Relations, 17 September 2008, at <http://babel.hathitrust.org/cgi/pt?id=pst.00 0065526903; view=1 up;seq=5>, 13 September 2015. 
Haushofer K., An English Translation and Analysis of Major General Karl Ernst Haushofer's Geopolitics of the Pacific Ocean. Studies on the Relationship between Geography and History, ed. L.A. Tambs, trans. by E.J. Brehm, Lewiston 2002 (Mellen Studies in Geography, 7).

Henley J., 'A Brief Primer on Vladimir Putin's Eurasian Dream', The Guardian, 18 March 2014, at <http://www.theguardian.com/world/shortcuts/2014/feb/18/brief-primer-vladi mir-putin-eurasian-union-trade $>$.

Herpen M. van, Putin's Wars. The Rise of Russia's New Imperialism, Lanham 2014.

Herspring D. (ed.), Putin's Russia. Past Imperfect, Future Uncertain, Lanham 2003.

Khalikov Y., Uzbekistani's Russian-Language Conundrum, Eurasianet, 18 September 2006, at <http://www.eurasianet.org/departments/insight/articles/eav091906.shtml>.

Kissinger H., Diplomacy, New York 1994.

Klump D.S., Russian Eurasianism: An Ideology of Europe, Wilson Center, 7 July 2011, at <https://www.wilsoncenter.org/publication/russian-eurasianism-ideology-empire>.

Kohr L., The Breakdown of Nations, New York 1978.

Kristensen H.M., Norris R.S., Status of World Nuclear Forces, Federation of American Scientists, 16 July 2009, at <http://fas.org/issues/nuclear-weapons/status-world-nuclear-forces/>.

Mackinder H.J., Democratic Ideals and Reality. A Study in the Politics of Reconstruction, Washington 1996 (Defense Classic Edition).

Mahan A.T., The Problem of Asia. Its Effect upon International Politics, New Brunswick 2003.

Mankoff J., Russian Foreign Policy. The Return of Great Power Politics, Lanham 2009.

Mearsheimer J.J., 'Why the Ukraine Crisis is the West's Fault', Foreign Affairs, Vol. 93, No. 5 (2014), at <https://www.foreignaffairs.com/articles/russia-fsu/2014-08-18/why-ukrainecrisis-west-s-fault $>$.

Mearsheimer J.J., The Tragedy of Great Power Politics, New York 2001 (The Norton Series in World Politics).

Meeting of the Valdai International Discussion Club, Kremlin News, 24 October 2014, at <http://en.kremlin.ru/events/president/news/46860>.

Mozorova N., 'Geopolitics, Eurasianism, and Russian Foreign Policy under Putin', Geopolitics, Vol. 14, No. 4 (2009), at <http://dx.doi.org/10.1080/14650040903141349>.

Nygren B., The Rebuilding of Greater Russia. Putin's Foreign Policy towards the CIS Countries, New York 2008 (Routledge Contemporary Russia and Eastern Europe Series).

Parffit T., 'Has Vladimir Putin Blinked over Ukraine?', The Daily Telegraph, 7 July 2014, at <http://www.telegraph.co.uk/news/worldnews/vladimir-putin/10951644/Has-VladimirPutin-blinked-over-Ukraine.html>.

Polelle M., Raising Cartographic Consciousness. The Social and Foreign Policy Vision of Geopolitics in the Twentieth Century, Lanham 1999.

Presidential Address to the Federal Assembly, Kremlin News, 12 December 2013, at <http:// en.kremlin.ru/events/president/news/19825>.

Putin V., 'A New Integration Project for Eurasia: The Future in the Making', Izvestia, 3 October 2011, at <http://www.russianmission.eu/en/news/article-prime-minister-vladimir-putinnew-integration-project-eurasia-future-making-izvestia-3->.

Putin V., Integration of Post-Soviet Space an Alternative to Uncontrolled Migration, RT News, 23 January 2012, at <http://www.rt.com/politics/official-word/migration-national-que stion-putin-439/>. 
'Road to War in Georgia: The Chronicle of a Caucasian Tragedy', Spiegel, 25 August 2008, at <http://www.spiegel.de/international/world/road-to-war-in-georgia-the-chronicle-of-acaucasian-tragedy-a-574812.html>.

'Russia Oil Row Hits Europe Supply', BBC News, 8 January 2007, at < http://news.bbc.co.uk/2/ hi/business/6240473.stm>.

Samaddar R. (ed.), Space, Territory and the State. New Readings in International Politics, Hyderabad 2002.

Sempa P.F., Geopolitics. From the Cold War to the 21st Century, New Brunswick 2009.

Sevim V.T., 'Eurasian Union: A Utopia, a Dream or a Coming Reality?', Eurasian Journal of Business and Economics, Vol. 6, No. 12 (2013).

Shenfield S., Russian Fascism. Traditions, Tendencies, Movements, Armonk 2001.

Shlapentokh D., Russia between East and West. Scholarly Debates on Eurasianism, Leiden 2007 (International Studies in Sociology and Social Anthropology, 102).

Sibley R., 'The Expansionist behind Putin', Ottawa Citizen, 1 May 2014, at <http://www.otta wacitizen.com/news/expansionist+behind+Putin/9801689/story.html>.

Telephone Conversation with UN Secretary General Ban Ki-moon, President of Russia, Kremlin, 2 March 2014, at <http://en.kremlin.ru/events/president/news/20357>.

Thom F., 'Eurasianism: A New Russian Foreign Policy?', Uncaptive Minds, Vol. 7, No. 2 (1994). 'UK Condemns Chechnya Ultimatum', BBC News, 7 December 1999, at <http://news.bbc. co.uk/2/hi/uk_news/politics/554075.stm>.

Ukhurgunashvili G., Putin's Brain? Geopolitics of Aleksandr Dugin, Banska Bystrica 2015, at <https://www.academia.edu/16094159/_PUTIN_S_BRAIN_Geopolitics_of_Aleksandr_Dugin $>$.

World Trade Organization, WTO membership rises to 157 with the entry of Russia and Vanuatu, 22 August 2012, at <https://www.wto.org/english/news_e/pres12_e/pr671_e.htm>.

Monika ERIKSEN is a PhD Candidate at the Institute for European Studies at the Jagiellonian University. She has studied Political Science at State University of New York, and obtained a Master Degree in International Conflict Analysis and Resolution from George Mason University as well as a Master Degree in European Studies from Jagiellonian University with a focus on Southeast Europe. Her academic interests deal with aspects of national identity building, international conflict resolution, ethnic conflicts and minority rights. She has worked and conducted research on issues related to Western Balkans, with a particular focus on Kosovo. She is an author of several articles, and has participated in various EU and UN-sponsored projects on civil society building in Kosovo as part of the Center for Civil Society Development in 2007-2008. 